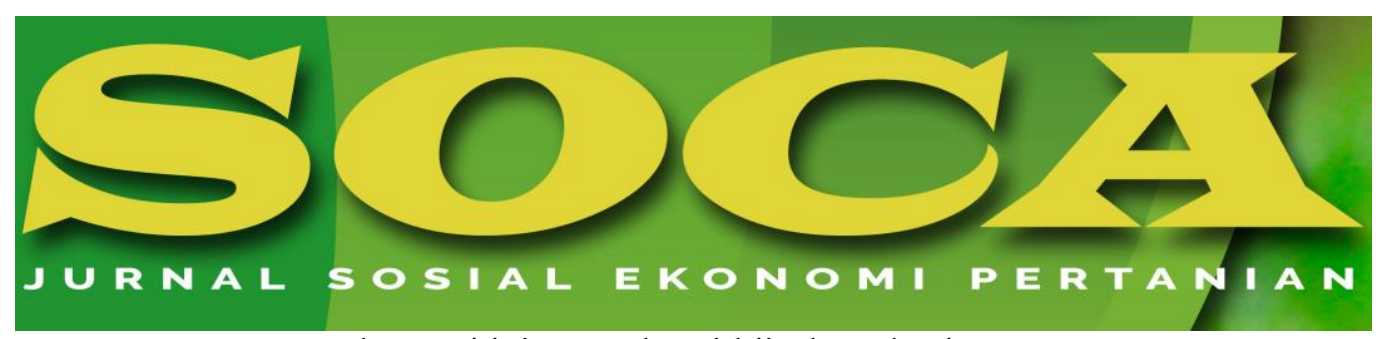

https://ojs.unud.ac.id/index.php/soca

\title{
The Policy of Non-Cash Food Aid Program (BPNT)
}

\author{
I Putu Cakra Putra Adnyana and Sabar Untung \\ Assessment Institute for Agricultural Technology (BPTP) West Nusa Tenggara \\ Email: Putucakra@yahoo.co.id and Untungsabar88@yahoo.co.id \\ Mobile: 081915881663 and 081917435223
}

Submitted: January 27th, 2020; Revised: April 21st, 2020; Accepted: May 28th 2020

\begin{tabular}{l}
\hline \\
\hline Keywords: \\
Policy; aid; \\
food; non- \\
cash
\end{tabular}

Abstract

The RASTRA Program ended in 2019 replaced by the Non-Cash Food Aid Card (BPNT). There were two important things in the BPNT program, which were free to choose the type of rice and prices that change from time to time. When the policy was not well prepared, it can trigger high prices and many speculators appeared that affected the price and stock of rice on the market. On the other hand, Bulog had prepared a change of strategy in distributing rice to the community. This certainly had a direct impact on the community or Bulog itself. So that research needs to be done with the aim to find out the benefits of the BPNT program for the community and its impact on the Bulog. The research aim was to determine the benefits of the BPNT program for the community and the impact of the program on the National Logistics Agency (Bulog). The scope of the activity was reviewing the results of studies or research related to Bulog. The data collected through deskstudy then analyzed descriptively. The government program was able to reduce the expense load of beneficiary families and provide more balanced nutrition on target, on time, increase program effectiveness and encourage financial inclusion among grassroots communities, but on the other hand during the transition period in 2019 Bulog endures losses due to the BPNT program, So we need the support from all stakeholders to solve these problems.

How to Cite (APA 6 ${ }^{\text {th }}$ Style):

Adnyana, I. P. C. P., \& Untung, S. (2020). The Policy of Non-Cash Food Aid Program ( BPNT ). SOCA: Jurnal Sosial Ekonomi Pertanian, 14(3), 456-465.

https://doi.org/https://doi.org/10.24843/SOCA.2020.v14.i03.p07 


\section{INTRODUCTION}

The mandate given to Bulog before 1998 was to maintain the stability of market rice prices for consumers and controlled grain prices at the farm level, and prepared rice stocks for routine distribution, emergency needs, or other needs. Starting in 1998 was the beginning of the implementation of the RASKIN Program Policy. The protection to the farmers through basic prices remained a top priority. While for the duty to stabilize consumer prices began to be reduced. The role of the National Logistics Agency (Bulog) to help the poor who were prone of food was increasing. According to Affif and Mears, (1982) Bulog's duty consisted of: (1) setting a base price high enough to stimulate farmers to engage in farming, (2) protecting the price of rice for consumers, (3) a decent price difference between producer and consumer prices can move the market, (4) a reasonable price correlation between foreign prices and domestic prices.

The RASKIN program began in 2002, where the RASKIN Program as part of the community's social protection program. But in its management RASKIN was often considered not on target. Then RASKIN was replaced by RASTRA which helped poor people, this program was also effective in maintaining the stability of rice prices. RASKIN was late in the fluctuation in extraordinary food prices. Food programs that were specifically designed to prevent the effects of the monetary crisis can actually affected prices.

In May 2019 the RASTRA Program was changed to the BPNT Card. The distribution of rice in 2018 amounted to 1.2 million tons then in 2019 it would be 354 thousand tons, in 2020 no more distribution. There were two important things in the BPNT program, which were price which can change and freedom in choosing the type of rice. The balance rice or commodities redemption price by the beneficiary community was very much determined by the strength of the seller and buyer so that it cannot be controlled.

In economic theory, high demand will be manifested as an increase in purchasing strength. In its implementation, high demand resulted in an increase in prices. Even more dangerous was that uncontrolled rice prices can trigger high inflation. On the other hand, Bulog had made several strategies in anticipating policy changes in the procurement and distribution of rice/grain by intensifying commercial marketing of rice even though the duty of maintaining the stability of rice prices on the market and the supply of stocks when emergencies continue to be performed. The changes in Bulog's strategy in distributing rice to the community certainly had a direct impact on the community or Bulog itself. So that research needs to be done with the aim to find out the benefits of the BPNT program for the community and its impact on the Bulog.

\section{RESEARCH METHODS}

The scope of activities was the BPNT program in Indonesia. The data collected through deskstudy then analyzed qualitatively descriptively which explained the phenomena that occurred through collecting research data by reviewing the results of studies or research related to Bulog such as, article of rice inventory control (Sartika, 2014; Yun, 2014), rice supply chain (Trisilawaty, et al , 2011), regulations, general guidelines of BPNT, BPS data etc., so it can provide an overview of the direct 
impacts felt by the community and the National Logistics Agency (Bulog) as a result of changing the model of rice distribution to the community (Nasir, 1988).

\section{RESULTS AND DISCUSSION \\ The Policy of Poor Rice Program (RASKIN)}

The RASKIN program policy was a social assistance program by the central government to the poor. With this program, it was expected to provide information on: 1) Food Security as well as Social Protection mechanisms at the target household level (RTS); 2) Stability of the price of rice in the market by providing aid of about 233 thousand tons from 2013 until 2015; 3) Relieve food needs and RTS expense; (4) Controlling inflation of subsidized rice prices from 2008 until 2015 with the RASKIN redemption price of $\mathrm{Rp} 1,600 / \mathrm{kg}$; 5) Maintaining national rice stockpile, in accordance with Presidential Instruction No. 3 of 2012 where the national rice procurement prioritized the procurement of grain/rice from the purchase of domestic farmers' grain/rice; 6) Food access for RTS; 7) As a place to absorb the crop yields of Rice Farming business; 8) Encouraging the economy in the regions; 9) Save expenses on low income belonging to RTS; 10) Preventing food insecurity and malnutrition.

Some obstacles of the RASKIN Program were the accuracy of the indicators and the availability of the budget. The determination of the amount of rice for RASKIN was determined according to the budget prepared by the government, if there was an adjustment made in the state budget (APBN) changes in the middle of the year, making it difficult in stock and distribution planning because it was not appropriate with the needs at the beginning of the year. Not to mention, the RTS data which changed very dynamically became the distribution barrier in the regions. There were still poor people outside the RTS who have not been able to receive poor rice aid because it has not been recorded as an RTS at BPS. Local policies and "willingness" among RTM in sharing were considered as deviations from the program.

Furthermore, price adjustments was different from those set due to geographical constraints, where the RTS's residence was far from the Distribution Point (TD), and the Sharing Point (TB) resulted in the RTS having to pay more to bring the rice closer to their residence. The role of local governments to help RTS achieved the right price needed to be encouraged by providing its APBD funds for RASKIN, such as: transportation cost subsidies. Besides going direct to RTS, it can be also through Warung Desa (Wardes), it was expected that the distribution of RASKIN will be closer and more gradually to RTS starting to be implemented in 2009 . The supply chain strategy or marketing was focused on efficiency and ability to respond to market needs (Chopra, and Meindl, 2007). This strategy was realized through the support of facilities and infrastructure, supply, information, prices, and other resources (Trisilawaty et al., 2014).

But according to the KPK of the RASKIN program, in its implementation still encountered KPK problems, 2014). So, some actions that need to be done were: (a) Improving the data base in an integrated manner (b) Changing ways of thinking through natura in kind aid with specific RTM targets where previous aid was in the form of rice subsidies so that RTM no longer issued redemption money to obtain rice (c) Bulog had the responsibility to maintain the quality of rice by buying at farmers through Bulog partners in the form of grain which was then grinded into rice and ensuring rice was received by the RTM (d) Distribution of rice was not required once 
a month when geographically it was difficult to reach by transportation facilities (e) Give full responsibility to the Regional Government and its staff to supervise, controlled in their respective regions for ensuring the distribution of rice (Kemenko Kesra, 2014).

The impact of the recommended policy recommendations were: (a) A higher budget must be provided by the Government, (b) The government allocated transportation costs sourced from the APBN and APBD so that the distribution of rice reached the RTS-PM, (c) It can be reviewed for each quantum RTS-PM who will get aid per month. This means that the Government was expected to be able to relieve the burden on poor households in meeting their food needs. Other impacts were: (a) absorbing domestic farmers' rice (DN) so that rice imports can be avoided, (b) motivating farmers to work on rice so that food self-sufficiency was achieved and sustainable.

\section{The Transformation from RASKIN to RASTRA then BPNT}

The Prosperous Rice Program (RASTRA) had a precious aim. In addition to help the poor, this program was also effective in maintaining rice price stability. RASKIN was assumed of contributing to food prices, because in November 2014 the distribution of RASKIN was late, as a result, the price of rice rose since early 2015. If RASKIN was late, the fluctuations in food prices were extraordinary. A food program that was specifically designed to prevent the effects of the monetary crisis can actually affected prices. The plan to replace the RASKIN program with the RASTRA program through the provision of food vouchers to low-income people (MBR). With this voucher, people can also shop for food other than rice.

Based on data from the Ministry of Social Affairs there were around five million of Beneficiary Families (KPM) that were still listed as recipients of the RASTRA social aid. In 2019 all RASTRA social aid recipients transferred to the Non-Cash Food Aid (BPNT). But Bulog, a small portion still distributed 354,825 tons of RASTRA rice in 2019 and will not distribute it again in 2020.

The BPNT program was launched as an effort to distribute food aid, so that it was more right on target, right in quantity and on time. Through this program, it was expected that the beneficiaries will be more flexible in choosing the type, quality, price, and place to buy food, while at the same time it was expected to improve the community's economy by empowering thousands of micro businesses such as kiosks/stalls/shops that do transaction through the banking system, encouraging productive behavior in the community and provide an opportunity to increase assets that have the potential to improve economic activity (Coordinating Minister for Human Development and Culture, 2017).

The transformation that occurred made Bulog as one of the BUMN to make a strategic change from the direction of the Social Aid to the commercial direction. Although it still continued to performed the role of stabilizing prices and providing stockpiles in an emergency, Bulog will direct the distribution of rice to people in need with non-subsidized prices. In other words, there were two functions of Bulog, which were as a stabilizer of rice prices and got profit by selling rice commercially. 


\section{The Advantage of Non-Cash Food Aid Program (BPNT)}

The central government has a food aid program under the name BPNT in collaboration with Bank Himbara (Mandiri, BNI, BRI, BTN), where every month a Beneficiary Family (KPM) can buy food at Electronic Store Joint Business Group Hope Family Program (E-Warung KUBE PKH) by using a Prosperous Family Card (KKS) (Coordinating Minister for Human Development and Culture, 2017).

This food aid was given to minimize the expenses burden of the beneficiary's family and to provide a more balanced salary that was right on target to beneficiaries and on time in its distribution. The decision to distribute social aid in non-cash using the banking system was intended to increase the effectiveness of the program and to make distribution more right on target, in addition to encourage financial inclusion among grassroots communities.

Four general principles in the distribution of BPNT, which were: 1) KPM was able to reach out and apply it; 2) KPM was given more choices and control about when, type, quality and how much, according to their needs; 3) KPM can be served by people's retail businesses; 4) KPM was given access to financial services. There were several benefits obtained from BPNT, which were: 1) Increased economic growth in the region, especially micro and small businesses in the market sector; 2) KPM food security increased, including poverty alleviation mechanisms and social protection; 3) Non-cash financial transactions can increased; 4) Public access to financial services can increased; 5) Distribution of social aid can be more efficient; 6) Growth of micro and small businesses (UMKM) so that they can increase economic growth in the region (BPNT General Guidelines, 2018).

\section{BPNT Registration Process}

The RTS-PM registration process in the BPNT Program was as follows: The Prosperous Family Program (PKS) began when the Ministry of Social Affairs (Kemensos) registered participants of the Beneficiary Family (KPM).

The participant registration process and preparations were performed after the Ministry of Social Affairs sent the Integrated Poor Handling Program Data to the Regional Government (Regency and City).

Furthermore, a notification letter contained technical registration at the determined place was sent to KPM, after the data was filled in by the prospective recipient and then processed in parallel and synergistically by the Himbara bank branch offices, village offices and mayor/district office.

After data verification was completed and opened an account at the bank, social aid recipients will get a Prosperous Family Card (KKS) to be used in taking non-cash aid in the form of food aid. 


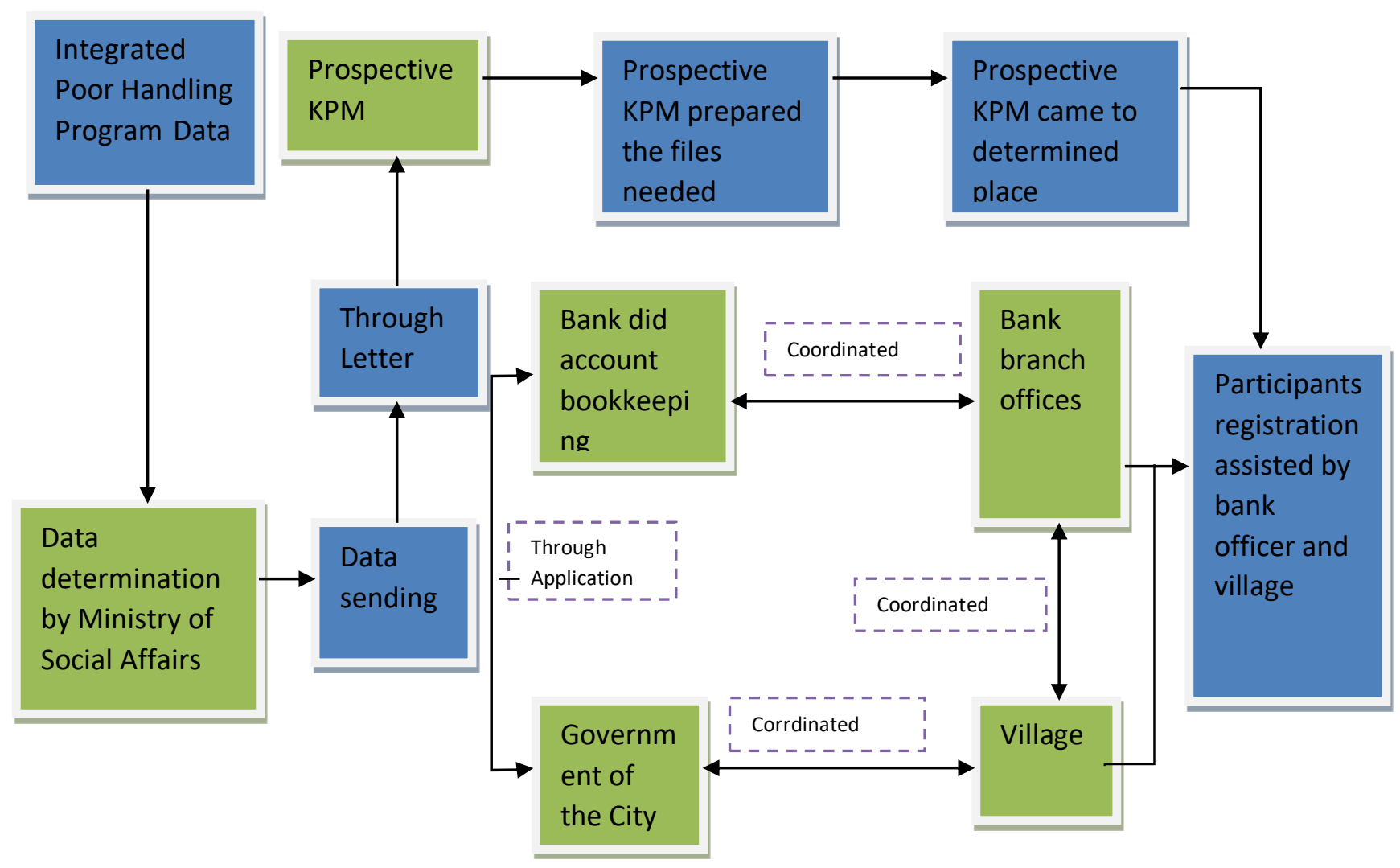

Picture 1 BPNT Registration Process

Source: BPNT General Guidelines, 2018

\section{BPNT Distribution Process}

The transactions to buy food must use the KKS in E-Warong, whenever there was a data change in RTS-PM data; the change was called Beneficiary Data Change (DPM).

On the KKS Chip recorded data of the amount of funds which distributed, funds that have not been used, and data on people who had used KKS to meet their food needs. Therefore the user can be more transparent and minimize its deviations. 


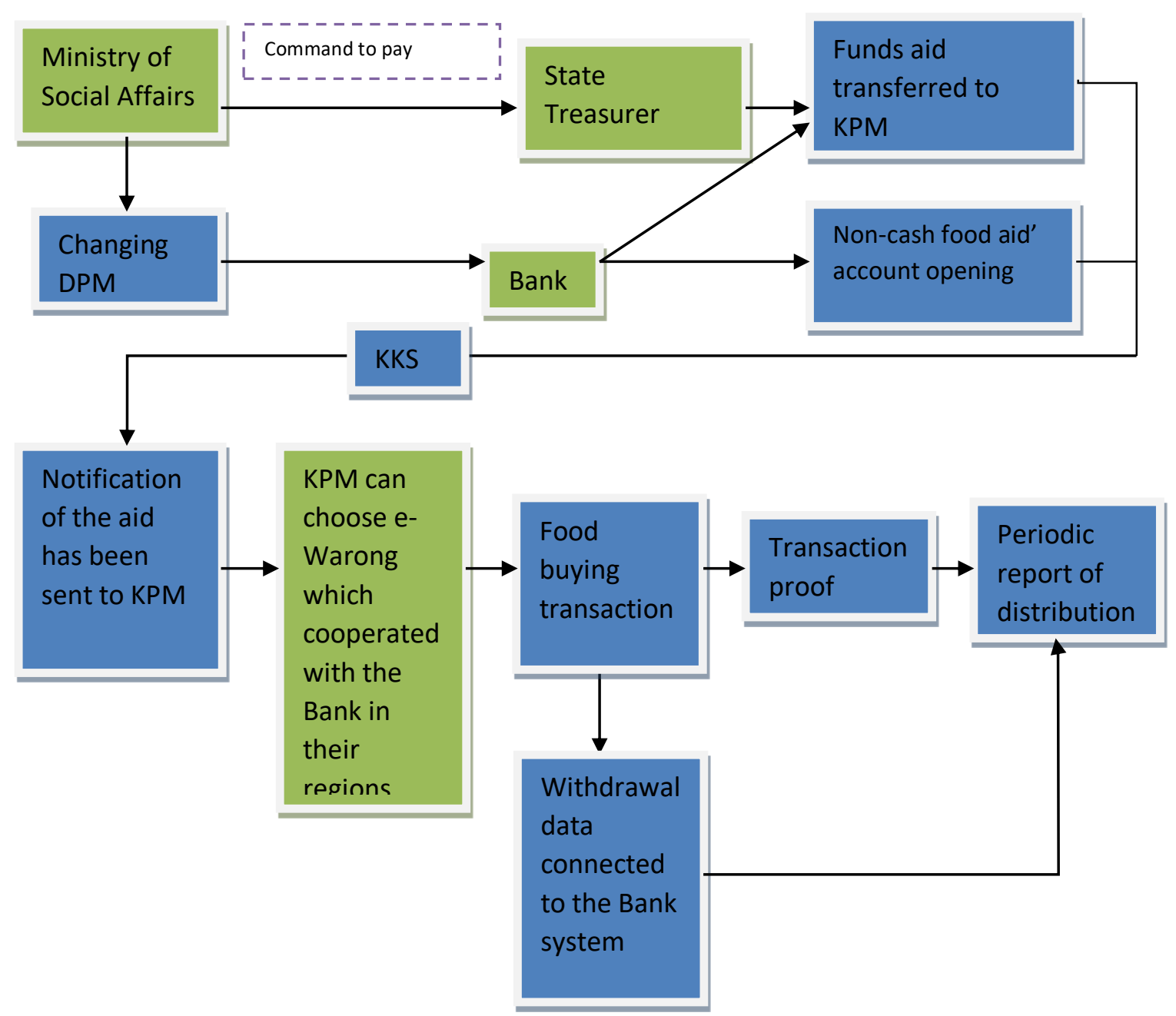

Picture 2. BPNT Distribution Process Source: BPNT General Guidelines, 2018

\section{The Problems of BPNT Program}

The BPNT program still left various problems, such as: KPM data was still questioned for their accuracy, availability of limited e-warong agents in the regions, inadequate infrastructure in some remote areas, and not all KPM that have been able to apply the Prosperous Family Card (KKS).

The change of RASTRA to BPNT had the potential for new requests of around seventeen million RTS-PM to enter the market. If it was not anticipated, the availability of adequate and quality rice will trigger an uncontrolled increase in rice prices, which can then lead to inflation. The increase in the price of rice can be caused by the increased demand for premium rice as a result of the freedom to choose the quality of the desired goods according to their respective interests, whereas previously the RTS-PM was only given medium quality rice. Based on the data of BPS Indonesia 2019, an annual price increase happened from 2017 amounted to $\mathrm{Rp} 11,535 / \mathrm{kg}$ to $\mathrm{Rp} 12,091 / \mathrm{kg}$ in 2019 . Rice consumption per capita in 2017 amounted to $97.43 \mathrm{~kg} /$ year in $201896.33 \mathrm{~kg} /$ year and was expected in 2019 $97.05 \mathrm{~kg} /$ year or an increase of $0.76 \%$ compared to 2018 (BPS Susenas, 2018). 


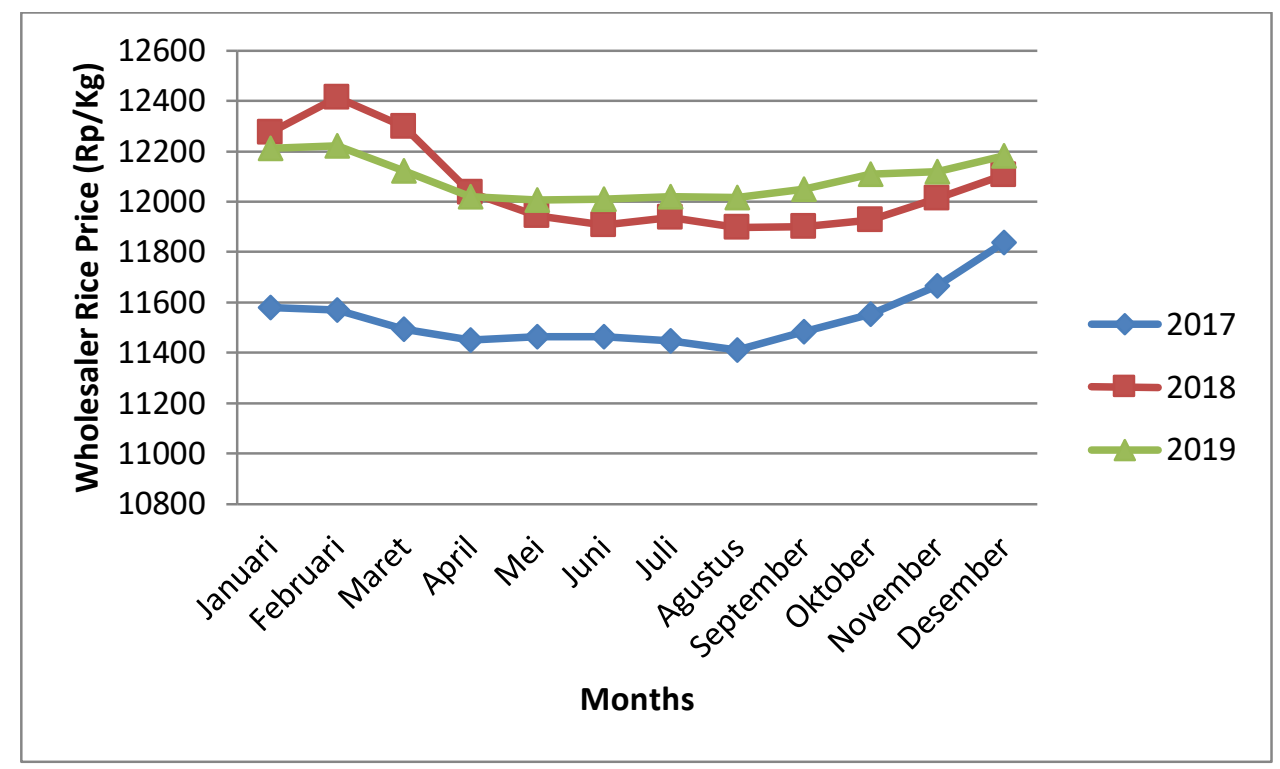

Picture 3. Average Rice Price in Indonesian Large Trade

Source: BPS Indonesia, 2019

Another problem of the BPNT program was that there were fraudsters and food mafias who heartless played with the distribution of rice aid to the poor for getting profit. A number of groups urged the Police and the Corruption Eradication Commission (KPK) to arrest all fraudsters who had deviate the BPNT program. The fraud mode was performed by packing the rice aid with a nice wrap. However, the quality of rice did not match the packaging, with a higher price, the beneficiary community got rice whose quality did not match the original. He estimated the material losses experienced by the beneficiary of Rp. 30 thousand per beneficiary.

This policy change also had an impact on the State Logistics Agency (Bulog) in September 2019 which recorded a loss in the Public Service Obligation (PSO) segment or a government assignment to Bulog of Rp. 955 billion. More precisely, the loss came from a decrease in the amount of the government assignment rice distribution role and a change in distribution to BPNT which was previously RASTRA (Vadhia, 2019). So the supports of all stakeholders to solve these problems were needed, such as the Minister of Finance, Minister of Agriculture, BPK etc. The two biggest problems faced by Perum BULOG nowadays were controlling rice supplies (Sartika, 2014; Yun, 2014) and supply chain performance (Ghozali, 2016; Sulistyowati and Natawidjaja, 2010; Sa'id, 2010).

The problem of rice supply, BULOG was often defeated by the rice mafia, so that the availability of rice on the market was often lacking which caused a significant increase in prices (Pratomo, 2015; Subandriyo, 2015; Jannah, 2018; Fakhrana, 2016). As a result, people's purchasing ability has decreased and can cause social and economic fluctuation. Not to mention other problems such as distribution inequality, reduced amount in the distribution process, lack of inventory, uncertainty, warehouse use planning. This was in accordance with the opinion of Trisilawaty et al, (2011); Yun, (2014); Sartika et al. (2014); Firdaus, et al, (2008) who stated that the lack of clarity in the rice supply chain at Bulog was caused by the unpredictable and unsystematic distribution of rice. 


\section{CONCLUSION}

Government programs were able to reduce the expense burden of beneficiary families and provide more balanced nutrition, right on target beneficiaries, and on time distribution, as well as increase program effectiveness and encourage financial inclusion among grassroots communities, but on the other hand in 2019 Bulog endured losses due to BPNT program.

\section{RECOMMENDATION}

The supports of all stakeholders to solve Bulog's problems because of policy changes were needed. Bulog must make internal repairs to be able to compete professionally with other private parties by improving the quality of rice and moving the surplus stock of Bulog to the deprived areas, so that the rice can be absorbed by the market. It is necessary to anticipate policies on the impact of rising rice prices on the market, so that they do not become counter-productive with the BPNT program.

\section{REFERENCES}

BPS Indonesia, 2019 https://www.bps.go.id/linkTableDinamis/view/id/963

Badan Pusat Statistik. Survei Sosial Ekonomi Nasional, Pengeluaran untuk Konsumsi Penduduk Indonesia tahun 2018. Jakarta dalam Buletin Konsumsi vol 10 no 1 2019. Pusat Data dan Sistem Informasi Pertanian. Sekretariat Jenderal Kementerian Pertanian. Jakarta

Chopra, S. and Meindl, P. 2007. Supply Chain Management: Strategy, Planning, and Operation, 3rd ed. New Jersey: Pearson Prentice Hall.

Fakhrana, R.S. 2016. Jaringan Mafia Besar di Balik Kasus Beras Oplosan. CNN Indonesia, diakses melalui https://www.cnnindonesia.com/nasional /20161014064716-12-165425/jaringanmafia-besar-dibalik-kasus-berasoplosan?.

Firdaus, M., Baga, L.M., Pratiwi, P. 2008. Swasembada Beras Dari Masa Ke Masa, Telaah Efektifitas Kebijakan dan Perumusan Strategi Nasional. IPB Press. Bogor.

Ghozali, M.I. 2016. Rantai Pasok Beras Pada Bulog Berbasis Neural Network. Jurnal Simetris, 7 (2): 743-752.

Inpres No. 3 Tahun 2012 tentang Kebijakan Pengadaan Gabah/ Beras dan Penyaluran Beras oleh Pemerintah.

Jannah, S.M. 2018. Berantas Mafia Pangan, Buwas Pakai Jejaring TNI-Polri. Finance. Detik.com, diakses melalui https:/ / finance.detik.com/beritaekonomi-bisnis/d-4012947/berantasmafiapangan-buwas-pakai-jejaring-tni-polri.

Kemenko Kesra, 2014. Pedoman Umum (Pedum) RASKIN 2015.

Komisi Pemberantasan Korupsi (KPK), 2014. Laporan Tahunan KPK 2014. 
Mears, Leon, 1982, Era Baru Ekonomi Perberasan Indonesia, Yogyakarta, UGM Press

Menteri Koordinator Bidang Pembangunan Manusia dan Kebudayaan, 2017. Pedoman Umum Bantuan Pangan Non-Tunai-2018. Cetakan Pertama, November 2017. Tim Pengendali Pelaksanaan Penyaluran Bantuan Sosial Secara Non Tunai. J1. Medan Merdeka Barat No.3, Jakarta Pusat 10110.

Peraturan Presiden RI tentang Rencana Kerja Pemerintah Tahun 2015.

Pratomo HB. 2015. Lima masalah beras di Indonesia, mulai dari berkutu hingga palsu. Merdeka.com, diakses melalui https://www.merdeka.com/uang/5masalah-beras-di-indonesia-mulaidari-berkutu-hingga-palsu.html

Sa'id Endang Gumbira. 2010. Manajemen Rantai Pasok Global Dan Antisipasi Peningkatan Kinerja Manajemen Rantai Pasok Pangan Di Perusahaan Umum BULOG. Vol 19, No 1 (2010): PANGAN. 51 -58

Sartika Ria, Emmy Darmawati, Ridwan Rachmat, 2014. Model Perkiraan Kebutuhan Pasokan Beras Untuk Program RASKIN (Studi Kasus Pada Perum Bulog Subdivisi Regional Cianjur). Jurnal, Vol 23, No 3 (2014): PANGAN. 220-231

Subandriyo, T. 2015 Mafia Pangan antara Ada dan Tiada. Koran Sindo, diakses melalui https://nasional.sindonews.com/read/1039236/18/mafia-panganantara-ada-dan-tiada-1441075271.

Sulistyowati, S., dan Natawidjaja, R.S. 2010. Analisis Rantai Pasok dan Rantai Nilai Beras di Jawa Barat. Jurnal Agrikultura, 21 (2): 128-136.

Trisilawaty Cory, Marimin Marimin, Noer Azam Achsani, 2011. Analisis Optimasi Rantai Pasok Beras dan Penggunaan Gudang Di Perum BULOG Divre DKI Jakarta. Jurnal Pangan. Vol 20, No 2 (2011): PANGAN : 177-197

Yun, Y. 2014. Pengendalian Persediaan Terhadap Distribusi Beras RASKIN Pada Perum Bulog Divre Jabar. Proseding Seminar Bisnis dan Teknologi, SEMBISTEK 2014 IBI Darmajaya 15-15 Desember 2014.

Vadhia Lidyana, 2019. Gara-gara Program BPNT, Bulog Ngaku Rugi Hampir Rp 1 Triliun. https://finance.detik.com/berita-ekonomi-bisnis/d-4793774/garagara-program-bpnt-bulog-ngaku-rugi-hampir-rp-1-triliun 